\title{
ESCRITURAS DE LUZ
}

\author{
TRAZOS DE LUZ. TESIS SOBRE LA FOTOGRAFÍA DE LA HISTORIA \\ EduARdo Cadava \\ Palinodia, \\ Buenos Aires, 2014 \\ ASTRAGALO, 20 (2015) \\ Attribution-NonCommercial-ShareAlike - CC BY-NC-SA \\ Roberto Fernández. CAEAU. Universidad Abierta Interamericana \\ Reseña, ISSN 2469-0503 \\ https://dx.doi.org/10.12795/astragalo.2015.i20.14
}

La versión inglesa de este libro editado en Princeton en 1997 donde su autor enseña, se llamó Words of Light, palabras de luz o palabras-luz con una voluntad mas escritural o discursiva que aquella más óptica y menos lingüística que entrega el concepto de trazos, más cercanos a ideogramas o grafismos mas íntimos o bien a alusiones o destellos, mas fugaces y menos codificados, quizá cercano en todo caso, a la idea casi mística de iluminación que usó Benjamin, el gran referente con quien dialoga Cadava en este libro, casi apelando a un tratamiento autópsico de las tan trajinadas Tesis sobre el concepto de Historia, título final que llevó el último e inacabado escrito de WB de 1939-40 y que en su primera edición americana Adorno tituló Sobre el concepto de historia.

Jugando con ese escrito Cadava subtitula el suyo Tesis sobre la fotografía de la historia en donde el concepto es sustituído por la fotografía y en el cuál, mediante lo que llama instantáneas en prosa, aborda 27 textos que cada uno trabaja en una noción siempre de original resonancia benjaminiana como Heliotropismo, Mortificación, Estrellas, Cesura, Lenguajes, Shocks, Epitafios que son alguno de sus títulos.

La fotografía no es más que una escritura de la luz -apunta Cadava-, una grafía producida por lo que Talbot (que en 1839 bautizó la fotografía como words of light) atribuyó al lápiz de la naturaleza (página 20), insistiendo que se trata de un medio-registro asociado a la memoria y a su función de recordación: por tanto algo muerto o cristalizado que asegura la referencia mnemotécnica de un hecho vital precedente. El lápiz de naturaleza es un calibre de luz, un aura de lo real que imprime y registra un testimonio desde entonces inmutable o inerte que escribe testamentariamente un recuerdo de lo que fue. Esa condición mortifera de la foto -aso- 
ciada al repudio que los primitivos le brindan a quiénes, mediante esa clase de captura de sus apariencias, quieren en el fondo, robarles el alma-Cadava la remite al interés que WB otorgó al exámen de algunas fotos primitivas del escocés David Octavius Hill, quién retrataba a las familias en el cementerio de Edimburgo y en medio de tumbas y panteones, vinculando ambas dimensiones de la recordabilidad: foto y tumba como aprehensiones o capturas de algo que tuvo vida y ya no la tiene. Podría decirse que el hogar de la foto es el cementerio.

La idea de captura como apropiación le sirve a Cadava para proponer otra justificación a su intento de correlacionar la noción de concepto en las Tesis benjaminianas con la de fotografía en sus tesis: explica asi que el término aleman begriff (concepto) remite en su origen etimológico a los verbos aprehender, asir, apropiar.

La relación biunívoca entre concepto e imagen (que es aquella con la que Foucault emprende su arqueología cognitiva de las palabras y las cosas) constituye el estatuto cognitivo del saber histórico: la historia no puede ocurrir -apunta Cadava, más bien explicando el suceso antes que el registro histórico- $\sin$ hechos de lenguaje, sin emergencia de imágenes (página 20), interesante expresión que yuxtapone sin articular lenguaje-imagen al poner una coma y no la $y$ inclusiva. Queda claro que el lenguaje-la imagen son materiales del sujeto histórico, no del historiador, que a su vez procesará otro sistema de lenguaje-imagen.

Por otra parte el libro trata de sumar declaraciones de otorgamiento de relevancia histórica al tándem concepto-imagen o por lo menos de relevancia histórica moderna al par concepto-fotografía. Benjamin refiere que el pensamiento histórico involucra tanto el movi- miento como su detención: eso es la foto (página 24). Moholy Nagy -el artista y fotógrafo de la Bauhaus al que tanto Benjamin como Cadava otorgan relevancia en este campo-indicó que el el Siglo XX pertenece a la luz y Bloch fue muy pertinente cuando definió la escritura de Benjamin como fotomontaje. El conocer fotografía, abundaría Moholy, equivale en la modernidad a saber usar el alfabeto y el analfabeto moderno sería aquel incapaz de comunicarse con imágenes.

Algunas operaciones esteticas innovativas de la modernidad podrían haberse originado en procedimientos de producción de imágenes fotográficas: las feéricas fotos parisinas de Atget - con su registración de la evanescencia de la ciudad en medio de una niebla real o provocada por la esfumatura del foco- podría haber significado un antecedente estético crucial de la poética surrealista.

Cadava también incursiona en entender la foto como una traducción, trasladando la noción de rescritura en diferentes lenguas el caso de la relación entre realidad y captura de la misma a través de la fotografía. Ambas ideas de traducción se unen en algo: tratar de preservar la diferencia del original. También existiría la posibilidad (quizá recurriendo a la noción de aparato ofrecida por Deotte) de relacionar los procedimentos de la fotografía y el psicoanálisis: ambos configuran aparatos de relacionamiento entre lo visible y lo in-visible, entre lo conciente ylo-conciente.

La operación de Benjamin fue también -indaga Cadava- la de conjuntar la filosofía de la memoria y el tiempo desplegada por Bergson como construcción conceptual del material de la historia con la proposición de una poética de la historia en Baudelaire (al ser capaz de instituir la via de historizar lo moderno que reco- 
rrerían artistas como Proust, Kafka o Bretcht, todos a su vez materia prima para el trabajo crítico de Benjamin). Todo además en torno de la dialéctica entre la vida histórica y la muerte artística: La imagen al igual que un souvenir concluye Cadava-es el cadáver de una experiencia (página 252).

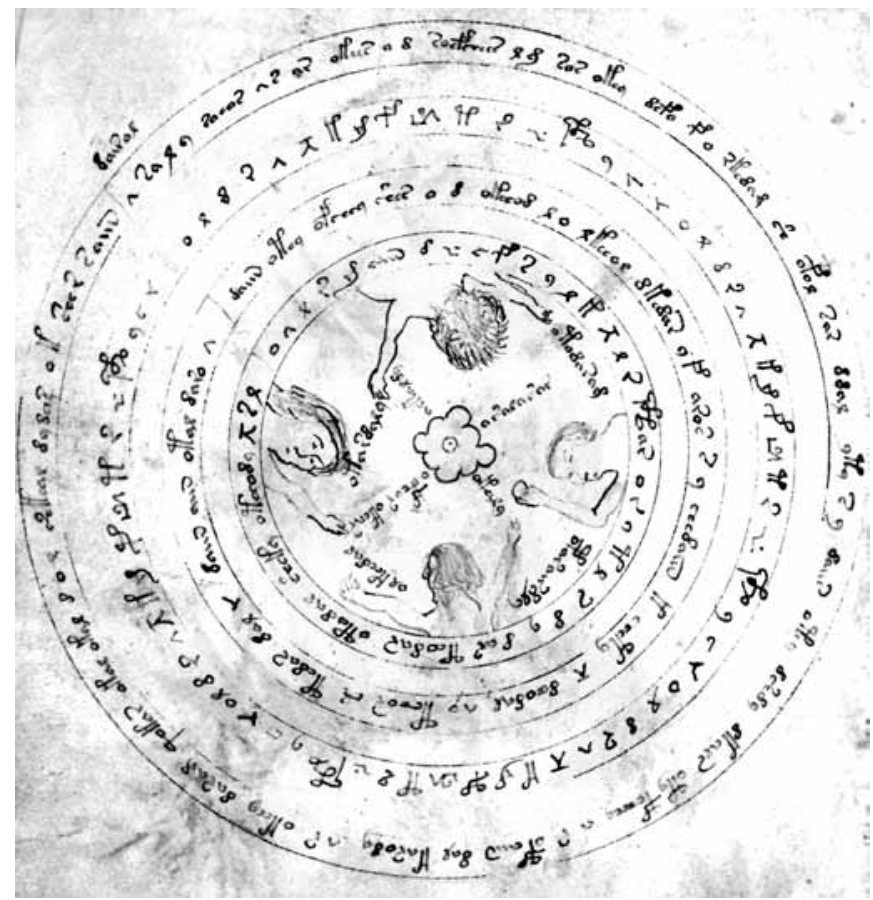




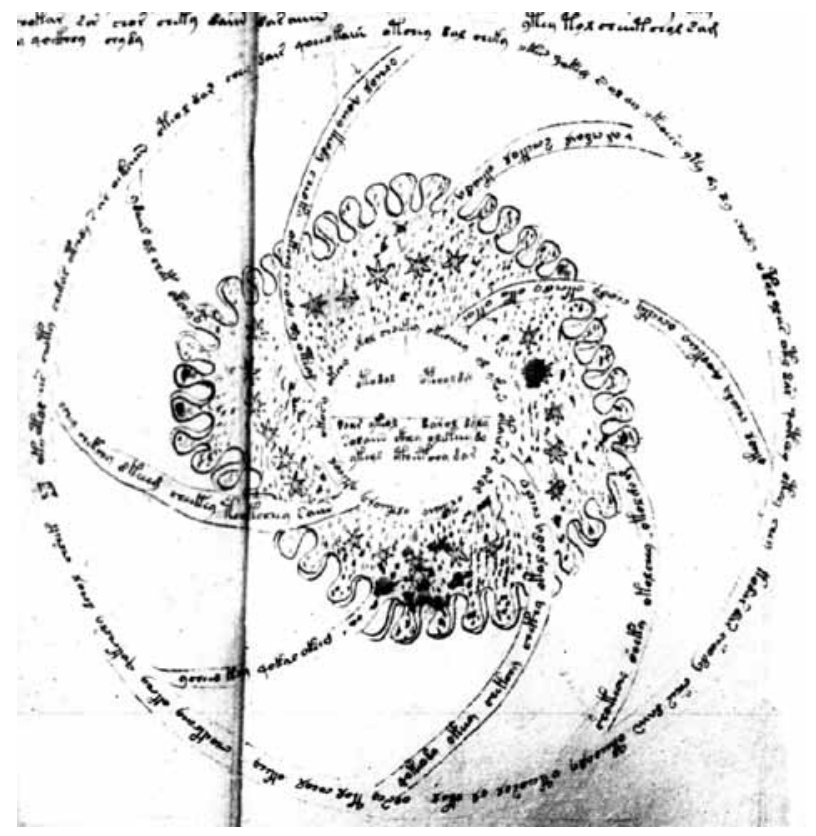

